\title{
BENTUK PELANGGARAN PRINSIP KESANTUNAN DAN PRINSIP KERJASAMA PADA FILM MANUSIA SETENGAH SALMON
}

\author{
Retno Narsiwi ${ }^{1}$, Ariyana ${ }^{2}$ \\ Universitas Muhammadiyah Tangerang \\ ariyana.mpd@gmail.com
}

\begin{abstract}
Abstrak
Penelitian ini bertujuan untuk mendeskripsikan bentuk pelanggaran maksim kerjasama dan maksim kesantunan pada dialog film Manusia Setengah Salmon yang disinyalir banyak memiliki pelanggaran prinsip dalam berkomunikasi, serta makna implikatur di dalamnya. Pendekatan yang digunakan dalam penelitian ini adalah pendekatan kualitatif dengan metode deskriptif analitik. Hasil penelitian ini yaitu dalam dialog yang mengandung pelanggaran prinsip kesantunan dan prinsip kerjasama. Penelitian ini ditemukan dalam prinsip kesantunan yaitu 1) pelanggaran maksim kearifan, 2) pelanggaran maksim pujian, 3) pelanggaran maksim kesepakatan, 4) pelanggaran maksim kerendahan, dan pada prinsip kerjasama ditemukan 1) pelanggaran maksim kualitas, 2) pelanggaran maksim relevansi
\end{abstract}

Kata Kunci: Prinsip Kerjasama, Prinsip Kesantunan, Film.

\section{A. Pendahuluan}

Bahasa berperan penting dalam kehidupan manusia. Keberadaan bahasa mempermudah manusia untuk saling berinteraksi dengan manusia lainnya. Interaksi dan segala bentuk kegiatan dalam masyarakat akan lumpuh tanpa adanya bahasa. Di dalam kehidupan masyarakat bahasa memiliki banyak fungsi, salah satunya adalah sebagai alat komunikasi. Bentuk komunikasi tersebut bertujuan untuk menyampaikan maksud dan berbagai kepentingan. Komunikasi adalah suatu proses penyampaian informasi dan maksud tertentu dari penutur kepada mitra tutur melalui bahasa. Berdasarkan pengertian di atas, diketahui bahwa setiap komunikasi melibatkan empat hal penting yakni pihak yang berkomunikasi, informasi yang disampaikan, pihak yang mendapatkan informasi, dan alat komukasi.

Seorang penutur harus menggunakan berbagai ragam tindak tutur agar dapat dipahami dengan tepat oleh mitra tuturnya. Pesan penutur terhadap mitra tutur dapat disampaikan dengan baik jika keduanya dapat saling memahami makna tuturan mereka. 
Ketika seseorang bertutur dalam suatu proses komunikasi, penutur tersebut mengharapkan tanggapan dari lawan tuturnya sesuai dengan tujuan yang ingin dicapai penutur. Apabila mitra tutur tidak memberikan tanggapan yang sesuai, maka komunikasi tersebut dikatan gagal.

Banyak faktor yang menyebabkan suatu proses komunikasi menjadi gagal. Faktor tersebut biasanya datang dari mitra tutur, seperti: mitra tutur dalam keadaan tidak sadar, mitra tutur tidak mempunyai pengetahuan tentang apa yang dibicarakan, atau mitra tutur tidak berkenan dengan cara penutur menyampaikan informasi. Faktor-faktor tersebut mengakibatkan kesalahpahaman dalam berkomunikasi. Selain itu, kesalahpahaman yang terjadi antara penutur dan mitra tutur dikarenakan penutur mengucapkan apa yang dimaksudnya berbeda dengan apa yang diucapkannya. Seringkali penutur memberikan informasi yang lebih dari apa yang dikatakannya, untuk dapat menangkap informasi tersebut mitra tutur harus mengerti konteks pembicaraan dan bekerja keras dalam memahami tanda-tanda yang diberikan oleh penutur. Hal ini biasa disebut dengan implikatur percakapan dalam berkomunikasi.

Maksim kerjasama mengharuskan penutur memberikan kontribusi percakapan sesuai dengan apa yang dibutuhkan pada saat berbicara, sedangkan maksim kesantunan berkenaan dengan aturan yang bersifat sosial, estetis, dan moral dalam bertutur. Oleh karena itu, apabila pemakai bahasa baik penutur maupun mitra tutur melanggar maksim tersebut, maka bukan tidak mungkin makna yang tersirat dari tuturan tersebut mengandung sebuah implikatur.

Pemakaian bahasa dapat ditemukan dalam berbagai kegiatan kehidupan, salah satunya dalam bidang hiburan khususnya perfilman. Lain halnya dengan kehidupan sehari-hari yang mengharuskan seorang penutur selalu menaati prinsip kerjasama dalam berkomunikasi, sebuah tayangan film terkadang sengaja melanggar prinsip percakapan dalam berkomunikasi. Pelanggaran tersebut dimaksudkan untuk menampilkan kesan berbeda dan lucu serta menjadi daya tarik untuk penonton.

Film adalah sebuah potret cerita kehidupan yang digambarkan oleh sebuah objek yang dimainkan di bioskop atau televisi. Cerita dalam film selalu menarik untuk ditelaah. Untuk dapat memahami pesan dalam suatu film seseorang tidak cukup dengan menontonnya saja, melainkan dengan memahami setiap isi percakapan di dalamnya. Percakapan tersebut haruslah mempunyai keterkaiatan agar penonton dapat memahami 
jalan cerita dari suatu film. Sebuah tayangan film merupakan aktualisasi perkembangan kehidupan masyarakat pada masanya. Bagaimanapun, film telah merekam sejumlah unsur budaya yang melatarbelakanginya. Termasuk pemakaian bahasa yang tampak pada dialog antartokoh di dalamnya.

Bahasa yang digunakan dalam sebuah film harus menarik agar makna yang ingin disampaikan dapat diterima oleh penonton, baik dari lapisan atas maupun lapisan bawah, tak jarang dalam sebuah film menggunakan implikatur-implikatur untuk menciptakan daya tarik tersendiri. Penggunaan implikatur dalam bahasa merupakan aspek yang terdapat dalam pragmatik suatu bahasa yang menarik untuk digali dan diteliti, begitu juga dengan pelanggaran prinsip percakapan didalamnya. Tak jarang sebuah tontonan komedi melakukan pelanggaran prinsip-prinsip dalam percakapan. Baik itu prinsip kerjasama maupun prinsip kesantunan. Pada dasarnya pelanggaranpelanggaran tersebut diciptakan untuk menambah kesan lucu pada film komedi.

\section{B. Kajian Pustaka}

Pada sebuah komunikasi, interaksi antara penutur dan mitra tutur akan menimbulkan sebuah percakapan yang memiliki maksud tertentu. Dalam menyampaikan maksud tersebut tentu akan ada implikatur yang terjadi. Cummings (2007) menyatakan "implikatur yang terjadi merupakan sebuah kerja sama antara penutur dan mitra tutur" (h. 14). Dari pernyataan tersebut dapat disimpulkan bahwa munculnya implikatur dalam sebuah percakapan dikarenakan adanya kerja sama antara penutur dan mitra tutur. Apabila penutur dan mitra tutur tidak bekerjasama, tentu percakapan yang terjadi akan mentah dan tidak bermakna.

Adanya kerja sama yang baik antara penutur dan mitra tutur dalam sebuah percakapan akan memudahkan informasi dalam penyampaian maksud yang ingin dicapai. Kesesuaian informasi yang didapat dari kerja sama ini membuat prinsip kerjasama percakapan menjadi sangat penting terlebih dalam pemunculan implikatur yang harus menyesuaikan dengan konteks dan situasi.

Prinsip kerja sama menyatakan bahwa penutur atau lawan tutur harus memberikan kontribusi percakapan seperti apa yang diinginkan. Prinsip kerja sama ini dilengkapi dengan empat maksim (aturan) yang menjelaskan bagaimana cara kerja prinsip kerja sama sebagai berikut: 


\section{Maksim Kuantitas}

Sebuah informasi yang dianggap cukup memadai tidak boleh melebihi informasi yang sebenarnya dibutuhkan oleh mitra tutur dalam aktivitas bertutur. Apabila suatu tuturan mengandung informasi yang berlebihan, maka tuturan tersebut dianggap melanggar maksim kuantitas dalam prinsip kerja sama.

2. Maksim Kualitas

Maksim ini mewajibkan setiap peserta percakapan mengatakan yang sebenarnya. Kontribusi percakapan hendaknya didasarkan pada bukti-bukti yang memadai (Putrayasa, 2014, h. 103).

\section{Maksim Relevansi}

Maksim relevansi dimaksudkan supaya kita berbicara sesuai dengan yang dipermasalahkan. Maksim relevansi merupakan maksim yang mengharuskan kita untuk berkomunikasi sesuai dengan tema permasalahan.

4. Maksim Cara atau Pelaksanaan

Maksim cara atau pelaksanaan mengharuskan setiap peserta pertuturan dalam aktivitas bertutur dapat menyampaikan informasi secara langsung, secara jelas, tidak kabur, tidak ambigu, dan secara runtut .

Masalah dalam berkomunikasi tidak selamanya selalu berkaitan dengan hal-hal yang bersifat tekstual saja, ada kalanya masalah tersebut sering berhubungan dengan persoalan yang bersifat interpersonal. Untuk menghindari masalah yang bersifat interpersonal tersebut, selain prinsip kerja sama seorang penutur juga harus mematuhi prinsip kesantunan. Dengan kata lain, penggunaan prinsip kesantunan ini bermaksud untuk menanggulangi hal-hal yang sukar diterangkan dengan prinsip kerja sama. Maksim kesantunan dapat dikatakan sebagai seperangkat aturan yang bersifat sosial, estetis, dan moral yang diikuti manusia dalam sebuah percakapan.

Fraser (1978) menjelaskan aturan kesantunan yang harus dipatuhi agar dapat terlihat santun dalam berujar yakni: Pertama, kesantunan itu adalah properti atau bagian dari tuturan. Kedua, pendapat pendengarlah yang menentukan apakah kesantunan itu terdapat pada sebuah tuturan atau tidak. Ketiga, kesantunan itu dikaitkan dengan hak dan kewajiban peserta tuturan (Chaer, 2010, h. 47). Maksud dari pernyataan tersebut adalah bahwa pertuturan seseorang dapat dikatakan santun apabila penutur memenuhi hak mitra tutur untuk mendapatkan informasi dengan sebenarnya dan mitra tutur 
memenuhi kewajibannya untuk menjawab pertanyaan yang diajukan oleh penutur atau sebaliknya. Apabila dalam suatu pertuturan kewajiban untuk menjawab atau menanggapi ujaran penutur diabaikan oleh mitra tutur, maka dikatakan tidak sopan. Hak dan kewajiban yang dimaksud ialah hak untuk mendapatkan informasi yang sebenarnya dan kewajiban untuk menjawab dan menanggapi ungkapan penutur atau mitra tutur.

Leech (2015) menawarkan enam jenis prinsip kesantunan, diantaranya:

1. Maksim Kearifan. Maksim ini menggariskan setiap peserta tuturan untuk meminimalkan kerugian orang lain atau memaksimalkan keuntungan bagi orang lain. Berikut ujaran yang mengungkapkan tingkat kesantunan yang berbeda.

2. Maksim Kedermawanan. Maksim kedermawanan menghendaki setiap peserta pertuturan untuk memaksimalkan kerugian bagi diri sendiri dan meminimalkan keuntungan bagi diri sendiri.

3. Maksim Pujian. Maksim pujian menuntut setiap peserta tuturan untuk memaksimalkan pujian kepada orang lain dan meminimalkan rasa tidak memuji kepada orang lain. Dengan maksim ini, diharapkan agar peserta tuturan tidak saling mengejek, saling mencaci, atau saling merendahkan orang lain. Sebaliknya, dalam maksim ini peserta tutur diharapkan dapat menyampaikan penjelasan kepada orang lain dengan perilaku yang lebih sopan.

4. Maksim Kerendahan Hati. Maksim kerendahan hati menuntut setiap peserta pertuturan untuk memaksimalkan ketidakhormatan pada diri sendiri dan meminimalkan rasa hormat pada diri sendiri.

5. Maksim Kesepakatan. Maksim kesepakatan mengharuskan agar penutur dan lawan tutur memaksimalkan kesetujuan diantara mereka dan meminimalkan ketidaksetujuan diantara mereka.

6. Maksim Kesimpatian. Maksim kesimpatian mewajibkan semua peserta pertuturan untuk memaksimalkan rasa simpati dan meminimalkan rasa simpati kepada mitra tuturnya. Bila mitra tutur memperoleh kekebahagiaan penutur wajib memberikan ucapan selamat. Sebaliknya jika mitra tutur memperoleh musibah penutur sudah sepantasnya menyampaikan rasa bela sungkawa sebagai tanda kesimpatian. 


\section{Metodologi Penelitian}

Penelitian ini menggunakan jenis penelitian kualitatif. Menurut Moleong (2012) penelitian kualitatif adalah penelitian yang bermaksud untuk memahami fenomena tentang apa yang dialami oleh subyek penelitian misalnya pelaku, persepsi, motivasi, tindakan, dan lain-lain, secara holistik, dan dengan cara deskripsi dalam bentuk katakata dan bahasa pada suatu konteks khusus yang alamiah dan dengan memanfaatkan berbagai metode alamiah (h. 6). Metode penelitian ini yaitu deskriptif-analitik, metode ini menggambarkan data dan menganalisis data. Data pada penelitian ini yaitu kutipan dialog dalam film Manusia Setengah Salmon yang mengandung pelanggaran prinsip kesantunan dan prinsip kerjasama. Sumber data dalam penelitian ini yaitu film Manusia Setengah Salmon dan buku teks yang mendukung penelitian ini.

Teknik pengumpulan data yaitu dengan teknik simak dan catat. Teknik simak yaitu peneliti menyimak ujaran yang berkaitan dengan pelanggaran prinsip kesantunan dan prinsip kerjasama dan teknik catat yaitu mencatat dialog yang mengandung pelanggaran prinsip kesantunan dan prinsip kerjasama. Teknik analisis data yaitu dengan cara 1) reduksi data yaitu memilih data yang berupa dialog yang berkaitan dengan pelanggaran prinsip kesantunan dan prinsip kerjasama, 2) penyajian data yaitu berkaitan dengan menganalisis data yang berkaitan dengan pelanggaran prinsip kesantunan dan prinsip kerjasama, 3) verifikasi dan simpulan yaitu mengecek kembali data dan menyimpulkan data yang berkaitan dengan pelanggaran prinsip kesantunan dan prinsip kerjasama.

\section{Pembahasan}

Analisis pada penelitian ini yaitu percakapan yang disebabkan oleh pelanggaran maksim kerjasama dan maksim kesantunan dari penayangan film Manusia Setengah Salmon karya Raditya Dika yang berdurasi 1 jam 35 menit 13 detik yang dianalisis yaitu (1) maksim kuantitas, (2) maksim kualitas, (3) maksim relevansi, (4) maksim cara, (5) maksim kearifan, (6) maksim kedermawanan, (7) maksim pujian, (8) maksim kerendahan hati, (9) maksim kesepakatan, dan (10) maksim kesimpatian. Namun, tidak semua pelanggaran maksim ditemukan di film ini.

\section{Dialog 1 :}


Dialog 1 terjadi ketika Dika kecil dengan sengaja mengerjai abang tukang bakso lalu abang tukang bakso marah dan mengguyur kuah bakso ke dalam celana Dika kecil. Tuturan "Rasain kamu!" yang disampaikan oleh abang tukang bakso menimbulkan pelanggaran maksim kearifan. Bentuk pelanggaran tersebut dikarenakan abang tukang bakso membuat kerugian bagi Dika kecil. Ujaran "Rasain kamu!" terdengar menghakimi Dika kecil, walupun Dika kecil berbuat jahil, tidak seharusnya abang tukang bakso menghukum Dika kecil dengan menyiram air panas ke dalam celana Dika kecil karena hal tersebut akan merugikan Dika kecil. Ujaran abang tukang bakso tersebut menegaskan kepada Dika kecil agar ia tidak mengulangi perbuatannya.

\section{Dialog 2 :}

Dialog 2 terjadi ketika Mbak Siti kesurupan. Ia berteriak sekencang-kencangnya dan membuat gaduh seisi rumah. Kalimat "Ya ampun! Tiup... tiup... cepet kita bawa dia ke Rumah Sakit Pertamina”. Merupakan respons yang diucapkan mama ketika dirinya panik atas kejadian yang sedang terjadi. Respons mama terhadap ujaran Dika pada dialog 2 ini dianggap melanggar maksim relevansi, Dika memberitahu mama akan keadaan pembantunya yang semakin membabi buta karena kesurupan mengharapkan mama berbuat sesuatu, tetapi mama menyuruh Dika untuk meniup pembantunya dan langsung membawanya ke Rumah Sakit Pertamina.

Seperti yang kita ketahui, kesurupan adalah suatu keadaan dimana seseorang akan melakukan hal-hal diluar kendalinya konon orang tersebut telah dirasuki arwah orang yang telah meninggal. Tentu respons mama dinyatakan tidak relevan karena kesurupan tidak akan sembuh hanya dengan ditiup berkali-kali atau dibawa ke Rumah Sakit Pertamina yakni sebuah Rumah Sakit umum untuk mengobati penyakit yang wajar. Jawaban mama mengimplikasikan bahwa mama memerintahkan Dika untuk membawa pembantunya ke Rumah Sakit Pertamina. Pada dialog ini melanggar maksim relevansi.

\section{Dialog 3 :}

Tuturan "Ini mah gak bakal diterbitin" yang dituturkan oleh Christian adalah bentuk pelanggaran dari maksim pujian. Bentuk pelanggaran dari maksim pujian yang dilakukan oleh Christian kepada penulis adalah Christian menghina hasil tulisan tersebut. Tuturan tersebut diucapkan oleh Christian karena ia merasa hasil tulisan 
penulis tidak bagus dan tidak memenuhi syarat sehingga menimbulkan implikatur penolakan oleh Christian kepada penulis.

\section{Dialog 4 :}

Kalimat "Sorry ya gak bisa di kantor gua di atas, ada penulis baru lagi ngamuk. Ancur semua!!” yang diucapkan Christian pada dialog 4 telah melanggar maksim kesepakatan, karena Christian sebagai penutur keberatan dan tidak setuju dengan keinginan Dika sebagai mitra tutur. Dika yang menginginkan berbicara di ruang kerja ditolak oleh Christian karena sedang ada penulis baru yang sedang mengamuk. Penolakan yang dilakukan Christian tersebut telah melanggar maksim kesepakatan. Dalam memenuhi maksim kesepakatan, dikatakan bahwa seorang penutur dan mitra tutur harus saling menciptakan kesepakatan antara mereka berdua. Maka jelas tuturan Christian telah melanggar maksim kesepakatan. Pelanggaran maksim kesepakatan yang dilakukan Christian mengandung penjelasan bahwa Christian menolak Dika untuk berbicara di ruang kerjanya.

\section{Dialog 5 :}

Dialog 5 terjadi ketika Christian sebagai editor Dika menolak hasil tulisan Dika karena menurutnya hasil tulisan tersebut belum layak terbit, Christian yang mengetahui Dika ditinggalkan agen naskahnya kemudian menawarkan agen naskah yang baru kepada Dika. kalimat "Kayaknya gue gak butuh agen naskah baru deh." yang diucapkan Dika pada dilaog 5 dianggap telah melanggar maksim kesepatakan. Kalimat ini menolak tawaran mitra tutur, penolakan yang dilakukan penutur menjadi tidak sopan karena tidak menghargai tawaran mitra tutur. Oleh karena itu, kalimat tersebut telah melanggar maksim kesepakatan. Pelanggaran maksim kesepakatan pada dialog 5 berimplikasi penolakan dari Dika kepada Christian karena Dika masih menginginkan agen naskah yang lama.

\section{Dialog 6 :}

Pada dialog 6 terlihat Dika dan Christian sedang berbincang-bincang mengenai hasil tulisan Dika yang mulai buruk semenjak Kosasih mengundurkan diri dan memutuskan untuk menjadi anggota boyband. Tuturan "Felling gue sih boyband dia gak bakal laku" yang diutarakan oleh Dika telah melanggar maksim pujian. Bentuk pelanggaran maksim pujian yang dilakukan oleh Dika adalah mengeluarkan kata-kata merendahkan atau menjelek-jelekan Kosasih. Pelanggaran maksim pujian tersebut 
merupakan kalimat ejekan untuk Kosasih yang menunjukkan bahwa Kosasih tidak memiliki suara dan wajah yang memenuhi kriteria utuk menjadi anggota boyband. Untuk memenuhi maksim pujian seseorang tidak diperbolehkan mengecam oranglain sedikit pun dan pujilah oranglaian sebanyak-banyaknya, bukan sebaliknya memberikan cacian yang menyakiti hati mitra tutur. Jadi, contoh di atas merupakan kalimat yang melanggar maksim pujian. Pelanggaran tersebut mengandung alasan bahwa Dika melarang apabila Kosasih beralih profesi sebagai boyband.

\section{Dialog 7 :}

Dika dan supirnya terjebak macet, Supir Dika menyarankan untuk lewat Rawamangun agar cepat sampai kerumah, tetapi Dika menolak dengan kalimat "Jangan Pak itu lewat rumah Jessica!” . Kalimat yang diucapkan Dika pada dialog 7 ini telah melanggar maksim kesepakatan. Sikap Dika yang tidak setuju lewat jalan Rawamangun dianggap telah merugikan supirnya karena Dika lebih memilih lewat jalan macet daripada lewat rumah mantannya. Penolakan dari Dika ini telah melanggar maksim kesepakatan karena tidak adanya pemufakatan antara penutur dan mitra tutur. Pelanggaran maksim kesepakatan ini berimplikasi bahwa Dika menolak melalui jalan Rawamangun karena tidak ingin teringat oleh Jessica mantan kekasihnya.

\section{Dialog 8 :}

Dika yang mengira bahwa Jessicalah yang akan menjadi cinta terakhirnya nyatanya berbeda dengan pandangan Jessica yang ingin mengakhiri hubungannya dengan Dika. Tuturan Jessica yang berkata “ Kita emang gak kadaluarsa, tapi kita udah tumbuh kearah yang berbeda." Kalimat ini dengan jelas telah menentang perkataan Dika sebagai mitra tutur, bahwa apa yang dikatakan mitra tutur sudah berlalu dan tidak harus dibahas lagi. kalimat tentangan yang diucapkan Jessica pada dialog 8 ini termasuk dalam pelanggaran maksim kesepakatan. Pelanggaran tersebut mengandung implikatur bahwa Jessica menolak dan tidak ingin melanjutkan hubungan dengan Dika lagi.

\section{Dialog 9 :}

Kalimat "Udah ya, aku udah sampai rumah. Kamu pulang gih ke rumah kamu!" yang diucapkan Jessica pada dialog 9 telah melanggar maksim kerendahan hati. Jessica sebagai penutur telah mengusir Dika sebagai mitra tutur secara langsung, sehingga membuat mitra tutur merasa tidak terhormat. Kalimat yang diucapkan Jessica mencerminkan perbuatan yang tidak memiliki rasa rendah hati terhadap oranglain. Jadi, 
kalimat tersebut dikategorikan telah melanggar maksim kerendahan hati. Pelanggaran yang timbul atas sikap Jessica ini mengimplikasikan perintah kepada Dika agar Dika segera meninggalkan rumah Jessica.

\section{Dialog 10 :}

Dialog 10 terjadi ketika Dika dan keluarga sedang makan malam bersama kemudian papa menyuruh Edgar memakan banyak bawang putih. Kalimat "Yaudah cepat kau makan. Kamu kan mau UAN, biar pas belajar kamu jadi gampang ingat bahan ujiannya, kau harus banyak makan bawang putih" merupakan tuturan papa pada dialog 10 yang dianggap melanggar maksim kualitas. Maksim kualitas dilanggar papa karena dengan perkataannya papa mengungkapkan bahwa harus banyak makan bawang putih agar mudah mengingat pelajaran saat ujian. Pada kenyataannya, bawang putih mengandung banyak antioksidan yang berguna bagi kesehatan tubuh dan belum ada bukti yang kuat bahwa bawang putih berkhasiat sebagai pengingat pelajaran saat ujian. Papa berkata seperti itu agar Edgar segera menghabiskan bawang putih yang ada dipiringnya. Dengan kata lain, perkataan papa tersebut telah melanggar maksim kualitas. Dikatakan bahwa dalam memenuhi maksim kualitas suatu percakapan seseorang tidak boleh mengatakan hal yang tidak ada buktinya dan tidak diyakini kebenarnya. Pelanggaran maksim kualitas tersebut mengandung implikatur yakni papa memerintahkan kepada Edgar agar memakan semua bawang putih yang ada dihadapannya.

\section{E. Simpulan}

Berdasarkan hasil analisis dan pembahasan yang dilakukan peneliti mengenai implikatur percakapan pada film Manusia Setengah Salmon, maka dapat peneliti simpulkan bahwa dalam dialog film Manusia Setengah Salmon terdapat berbagai implikatur percakapan yang timbul akibat pelanggaran maksim kerjasama dan maksim kesantunan. Pelanggaran maksim kerjasama terjadi apabila pada dialog film Manusia Setengah Salmon penutur tidak memberikan kontribusi yang sesuai dengan apa yang dibutuhkan dalam percakapan, sedangkan pelanggaran maksim kesantunan terjadi karena penutur tidak memperhatikan hal-hal yang terkait dengan kesantunan, seperti moral, estetika, dan nilai sosial dalam berkomunikasi. 
Lingua Rima: Jurnal Pendidikan Program Studi Bahasa dan Sastra Indonesia

Vol. 7 No. 1 Januari 2018

\section{DAFTAR PUSTAKA}

Chaer, Abdul. 2010. Kesantunan Berbahasa. Jakarta : PT. Rineka Cipta.

Cummings, Louise. 2007. Pragmatik Sebuah Perspektif MultidisiplinerPragmatics, A Multidisciplinary Perspective. Yogyakarta : Pustaka Pelajar.

Leech, Geoffrey. 2015. Prinsip-Prinsip Pragmatik. The Principles of Pragmatics. Jakarta : Universitas Indonesia.

Moleong, Lexy J. 2012. Metodelogi Penelitian Pendidikan. Bandung:PT Remaja Rosdakarya.

Putrayasa, Ida Bagus. 2014. Pragmatik. Yogyakarta : Graha Ilmu. 